\title{
SIGNIFICANCE AND POSSIBILITIES OF MAJOR ACCIDENT INSURANCE
}

\author{
Pavla Jindrová, Radim Jakubínský
}

\section{Introduction}

The development of human society places continuously increasing demands on its production. This brings to the society not only positive but also negative effects. Along with the development of industrial production, people have to face associated risks. Industrial accidents, which have occurred recently, still have a negative impact on human life, health, the environment and the economy.

Major accidents are defined as events resulting from uncontrolled developments during an industrial activity, such as a serious leakage, fire or explosion, which may immediately or subsequently lead to serious threat to individuals in or outside the premises, or to the environment, in which one or more hazardous substances are involved.

This article deals with different aspects and issues of major accidents with focus on the prevention of their occurrence and possible consequences. Since the risks of major accidents take catastrophic proportions, the quality legislation on this issue is needed. Overview of legislative actions is in the separate chapter of article. This legislation imposes to industrial companies with the risk of major accident the obligation of liability insurance for damages caused by the realization of these risks. The main objective of the article is to present the possibility of loss distribution of major accidents and simulation of potential extreme losses which are necessary for determining the premiums.

For the sake of illustration have been selected the major accidents and their consequences since the early twentieth century. The experience gained from these and other disasters have played a significant role in the development of legislation in relation to the prevention and liquidation of consequences of major accidents.

Minamata, Japan (1932-1968): The Company producing fertilizers released a total of 27 tons of mercury compounds into the sea. The result was a mass poisoning of local residents called Minamata disease. In the wake of this event, 2,000 to 3,000 people died. [6]

Seveso, Italy (1976): An explosion of a chemical reactor in the chemical plant of Givaudan company. The company's management announced that it had been a common accident and they failed to provide information about the leakage of toxic substances. It was as late as seventeen days after the accident that the factory management admitted that about two kilograms of dioxin leaked in the air, an amount of poison capable of killing 19,000 people. [5]

Bhopal, India (1984): Bhopal disaster is considered to be the worst industrial accident in the world. It started in a plant of the U.S. Company Union Carbide India Limited, producing pesticides, where deadly hydrogen cyanide gas and methylisocyanate (MIC) escaped. To this date, more than 20,000 people died and approximately 500,000 were injured as a result. [1]

Cubatão, Brazil (1984): An explosion in a petrochemical plant of Petrobas resulted in a fire in local slums. The amount of demises was due to the complete burning of some sites never precisely determined; it is estimated to be approximately 500 .

San Juan Ixhuatepec, Mexico (1984): A series of explosions in the large warehouse LPG Company Petroleos Mexicanos destroyed part of the city. About 500 people died.

Sandoz, Switzerland (1986): A fire in the agro-chemical company Sandoz warehouse caused the release of toxic agrochemicals into the air, but also about 30-40 tons of these chemicals escaped into the Rhine River. Mixture of substances in the river contained pesticides, dioxins, mercury, chlorine compounds, fluorescent dyes, organophosphates and others. Ciba-Geib, chemical company found 
close to this site, attempted to make use of this situation releasing 400 litres of atrazine into the river, believing this will not be revealed. Chemicals immediately caused the death of aquatic animals in the river. 100 tons of fish were killed and pollution of the Rhine reached as far as the Netherlands. [3]

Baia Mare, Romania (2000): Many experts believe that it is Europe's worst environmental disaster since the Chernobyl explosion. A dam holding back 100,000 cubic meters of contaminated water burst contaminating drinking-water supplies for more than 2.5 million Hungarians. Due to the toxicity of cyanide in water, especially around the basin of the Tisza, virtually all living organisms perished along the river. Further southwards, in the Serbian part, approximately $80 \%$ of aquatic life was killed. Two years after, the ecosystem began to return to its original state, although still far from the level before the disaster. [5]

Enschede, The Netherlands (2000): Fire at S.E. Fireworks caused a subsequent explosion of fireworks that the company had produced. Numerous explosions ensued within the following 30 minutes, devastating an area of $5 \mathrm{~km}^{2}$. The fire spread to a neighbouring brewery. The resulting cloud of smoke from the two companies was seen at a distance of $60 \mathrm{~km}$. In this disaster, 22 people lost their life, including four fire-fighters, and over 940 people were injured. It destroyed approximately 500 apartments, 1,500 homes, 60 businesses. [5]

Toulouse, France (2001): Explosion in the AZF chemical factory. It was equivalent to 2040 tons of TNT, it caused a tremor of 3.4 on Richter scale and was heard up to a distance of $80 \mathrm{~km}$. The explosion caused a total of 29 deaths, 2,500 serious injuries and 8,000 minor injuries. Damages paid out to insurance claims exceeded $€ 1.5$ billion. [5]

West, Texas (2013): Ammonium nitrate exploded in a fertilizer factory. As a result 15 people died, nearly 200 people were wounded and 150 buildings were destroyed or damaged. The essential information, however, is the fact that the company had liability insurance for damages only in the amount of one million dollars, but the total damage exceeded one hundred million U.S. dollars. With respect to the total damage, it may sound inadequate that the company was fined $\$ 118,300$ aggregately. In many states, including Texas, there is no legal obligation for the company to conclude liability insurance for the damage with the insured sum corresponding with the range of possible damages.

\section{Development of the Number of Accidents}

Human society is also exposed to the action of natural causes, often in the form of natural disasters. The number and consequences of man-made disasters is increasing with the development of human society. Development of industrial production also brings about the risk of major accidents.

Figure 1 shows the development of the number of disasters caused by human influence, compared to natural disasters between 1970 and 2012. This data shows a long-term growth of both types of catastrophic events. The chart shows that from 1970 onwards, the year 2010 is the first year where a higher occurrence of natural disasters appeared more than manmade disasters. This is also one of the alarming signals for the society to protect themselves and their environment from the effects of manmade disasters.

The primary challenge for the company is to take such measures so that no major accidents occur. However, people must be adequately prepared for possible explosions, fires, spills, and other serious faults. For this reason it is advisable to use emergency scenarios. Damages arising from industrial disasters can reach extreme values of billions of Euros. If a company should be able to bear the financial consequences of major accidents, it is necessary to have insurance that covers possible damages in an adequate amount. At this point it should be noted that the insurance company itself, however, cannot bear the risks in such volumes that are typical of these risks. It is therefore necessary to negotiate ensuring of each insurance contract.

\section{Legislation at Issue Prevention of Major Accidents}

The need for legislation for operators of industrial facilities and organisations, which are threatened by major accidents, was established immediately after the first occurrence of serious events.

Urgent talks on a new EU directive on whole regulatory framework in ensuring the safety of hazardous installations started after 
200

150

100

50

0

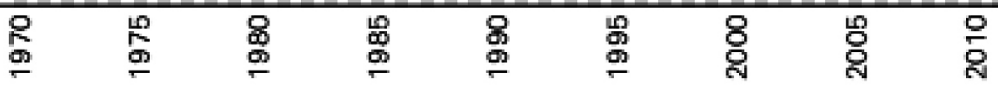

Source: own

the explosion of cyclohexane in the factory NYPRO Ltd. in Flixborough (UK, 1974). Over the next two years in the European Community framework occurred three additional serious chemical accidents: Beek (Netherlands, 1975), Manfredonia (Italy, 1976) and Seveso (Italy, 1976). [5]

In the light of these catastrophic accidents, it was clear that new legislation to improve the safety of industrial sites, planning for emergencies off-site accidents and dealing with the aspects of broader regional and crossborder industrial safety is needed. Directive Seveso, prepared in February 1977, which was adopted by the Council of Ministers of the European Community on 24 6th, 1982, is the result of those efforts. The following measures have to be adopted by individual Member States no later than January 8th, 1984. [18]

The Directive applies to the prevention of major accidents which may be caused by certain industrial activities, and to limit their consequences for a man and the environment. It focuses on the convergence of the measures taken by the Member States in this area. Article 1 defines terms such as industrial activity, operator, major accidents and hazardous substances.

The Directive was modified twice, in 1987 Directive 87/216/EEC of 19 March 1987 (Official Journal No L 85 of 28 March 1987) and the 1988 Directive 88/610/EEC of 24 November 1988 (OJ L 336 of 7 December 1988). Both amendments aimed to extend the scope of this Directive, largely in order to include the storage of hazardous substances. [18]

Changes occurred in response to a major accident in the Union Carbide factory in Bhopal, India in 1984 and accidents in the Sandoz warehouse in Basel, Switzerland in 1986.

Seveso I does not apply to nuclear facilities and plants processing radioactive substances and materials, military equipment, production and separate storage of explosives, gunpowder and ammunition, mining and other mining operations, equipment used for the disposal of toxic and hazardous waste, which are subject to Community law, if their aim is to prevent major accidents.

As the Council of Europe and representatives of the Governments of the Member States sitting in the Council stressed the need for a more effective implementation of Directive 82/501/EEC and called for a review of the directive which, if necessary, included a possible extension of the province scope of Directive and a greater exchange of information in this field between Member States. Also the need for improved management of risks and accidents was stressed. In addition, the accident in Bhopal and Mexico highlighted the danger posed by the proximity of residential 
buildings and dangerous areas. Last but not least, from the importance and benefits of informing the individual Member States was on December 9th, 1996, a new Directive 96/82/EC accepted, known as the Seveso II. [6]

Due to severe industrial accidents in Toulouse, France, in Baia Mare, Romania and Enschede, in the Netherlands and conclusions of studies on carcinogens and substances dangerous to the environment was Seveso II extended by Directive 2003/105/EC. The new Directive requires Member States to ensure a very detailed appraisal of risks by using possible accident scenarios that cover risks arising from storage and processing activities in mining, storage of pyrotechnics and explosives storage of ammonium nitrate based fertilizers [5]

The main reason for replacing the Seveso II Directive is a change in the system of classification of dangerous substances established by the European Directive No. $1272 / 2008$ of December 16th 2008, about classification, labelling and packaging of substances and mixtures. It was also necessary to clarify and update certain parts of the directive, to improve the implementation and enforcement of the Directive. In total, in the Seveso III (2012/18/EU) is listed 32 reasons. This Directive was adopted on July 4th, 2012, published July 24th, 2012, coming into force on August 13th 2012, to be implemented by May 31st, 2015 with the exception of the implementation of the Article 30, with the latest date February 14th, 2014. This part applies to heavy fuel oils.

Seveso III Directive is extended to onshore underground gas storage facilities. The Seveso II directive defines 8 concepts: plant, equipment, operator, hazardous substances, major accident hazards, risks and warehouse. The new Seveso III Directive defines 19 concepts, including 7 from the previous directive (excluding concept store).

The Seveso I, II and III, which are gradually released by the European Economic Community, the European Community and the European Union, are incorporated by individual Member States into their national legislation. In the Czech Republic, the law No. 59/2006 Coll is being addressed. The legislation also includes access to risk assessment, emergency scenarios and plans, the need for insurance, public access to information and many other serious measures.
According to Law No. 59/2006 Coll., about the prevention of major accidents, a severe accident is defined as an abnormal, partially or totally uncontrollable, spatially and temporally bounded event, such as a major leakage, fire or explosion, which occurred or the origin is imminently threaten in the context of with the use of the building or facility in which the hazardous substance is manufactured, processed, used, transported or stored, and leading to serious danger or serious impact on the lives and health of people, livestock and the environment or harm to property. [17]

This law pertained to approximately 150 industrial companies in the Czech Republic and established basic obligations for operators of these objects. It can be said that this law represented a significant contribution to the prevention from major accidents in the Czech Republic. However, it is clear that most companies were not sufficiently prepared to fulfil obligations stemming from this law; therefore the safety documentation was in large numbers repeatedly returned for reprocessing [1].

Law No. 59/2006 Coll. was partially amended several times and by the $1^{\text {st }}$ of March in 2010 came into effect the law No. 488/2009 Coll. that amends the law No. 59/2006 Coll., about the prevention of major accidents caused by dangerous chemicals or chemical preparations and about amending the law No. 258/2000 Coll., about the protection of public health and amendment to some related laws. [17]

Legislation of liability for damages incurred as a result of major accident is newly found in $\S 12$. The operator is obliged to conclude new insurance within 100 days from the entry into force of the decision on the approval of the security software or security reports. The limit of indemnity must reflect the range of possible impacts of severe accidents, which are currently listed in the approved security program or in an approved safety report. [17]

In the new legislation are specified individual administrative offenses in a separate $\S 36$, which is used in $\S 37$, which deals with fines, while in the previous law, the individual administrative offenses are listed right at the individual level of fines.

The legislation of major accidents in the Czech Republic uses a total of five instruments of protection, namely:

- Inclusion of an object or device. 
$\square \quad$ The obligation of the operator to prepare a list of hazardous substances; propose categorization to group $\mathrm{A}$ or $\mathrm{B}$, or handle the protocol on non-inclusion.

- Risk analysis, security program and report.

$\square$ The obligation of the operator to perform analysis and evaluation of risk of a major accident and on its basis to process safety program for prevention of major accidents for the group $A$, group $B$, then a safety report.

- Plan of the physical protection of the building or facility.

- Internal and external emergency plan.

- Liability insurance. [8]

\section{Major Accident Insurance}

For insurance of major accidents in the Czech Republic it is compulsory to conclude contractual insurance, with respect to the Law No. 59/2006 Coll. For serious industrial accident insurance, $\S 12$ of Law No 59/2006 Coll. must be abided by, where the limits for insurance are set. The level of limit of insurance benefit must reflect the range of possible impacts of severe accidents, which are currently listed in the approved security program or in an approved safety report. The level of limit of insurance benefit agreed by the operator for the testing of the operation stage should reflect the range of possible impacts of major accident based on the results of risk analysis and assessment, submitted to the Regional Office. [17]

Total insurance premium is determined by the relation:

$$
C P=Z P * K_{S P} * K_{R M}+D N,
$$

where:

$C P$ is the total insurance premium,

$Z P$ is the basic insurance, including participation,

$K_{S P}$ is the coefficient of participation,

$K_{R M}$ is the risk factor,

$D N$ are additional costs.

For calculation of the risk factor, a partial risk analysis need be carried out, the result of the evaluation is $h$, wherein:

$$
1 \leq h \leq 5,
$$

while 1 is the best rating and 5 the worst rating; corresponding with the highest possible risk.
Subsequently, the overall coefficient of the risk factor $K_{R M}$ is set, where:

$$
0.3 \leq K_{R M} \leq 6 .
$$

The total insurance premium increases when increasing the sum and increasing relative participation decreases the total insurance premium. The basic problem in determining the premium according to (1) is correct identification of the basic premium. For this aim, the insurance company needs to know the extent of damage probability models including information about possible extreme losses. In the next section, the issue of modeling and simulation of extreme damages is dealt with.

\subsection{Modelling and Simulation of the Extreme Losses}

Serious industrial accidents are often classified as extreme, catastrophic damages with the insurance claims amounting to billions of euros.

Extreme values theory is used to assess the risks of highly improbable events. To such events belong serious industrial accidents and also various natural disasters (hurricanes, floods, earthquakes, fires, etc.) and man-made disasters, including nuclear accidents and terrorism.

As already shown in figure 1, the amount of catastrophic events has a tendency to increase. The total insurance benefit of insurance companies is made up of $80 \%$ payment of damages from such events, while their share in the total number of insurance benefit is approximately $20 \%$. Insurance companies are forced to innovate and continually evaluate their approaches to risk assessment and individual insurability of risks associated with the design of insurance products. Both these facts are of course significantly reflected in the prices of insurance.

To be able to model and simulate the extreme losses of major accidents, the following sections provide a theoretical procedure for practical use of quantile function and order statistics for the simulation of extreme losses. More details about catastrophic risk management and about modeling catastrophic loses you can fine in [14] or [16]. 


\subsection{Quantile Model}

In the portfolios of serious industrial accidents insurance is the probability of occurrence of the extreme losses higher in comparison with conventional insurance portfolio. These claims have a large financial impact on insurance companies, so it is important for the insurer to know the probability model that adequately describes the insurance losses also in the right-hand tail.

For the extreme losses modelling the long or heavy tailed probability distributions are used. The Pareto distribution is often used as a model for claim amounts needed to obtain well-fitted tails [12]. Random variable $X$ has a distribution with the heavy tail, if applicable:

$$
\begin{aligned}
& \lim _{x \rightarrow \infty} e^{\lambda x} P(X>x)=\lim _{x \rightarrow \infty} e^{\lambda x} \bar{F}(x)=\infty, \\
& \text { for } \lambda>0 .
\end{aligned}
$$

Quantile functions application is one way of modelling the claim amounts and subsequent simulation of extreme losses.

When respecting specific basic rules, advantageous features of quantile functions allow to combine and edit functions in such a way that the resulting shape is nondecreasing, quantile function again, with statistically interpreted parameters [7], [15].

Quantile function $Q(p)$ is defined for each real $p, 0 \leq p \leq 1$ by relation:

$$
Q(p)=x_{p} \text {, for which } F\left(x_{p}\right)=p .
$$

Quantile function $Q(p)$ is then defined as the inverse to the distribution function $F(x)$. The value $x_{p}$ is called $p$-quantile. By differentiating the function $Q(p)$ by $p$ we obtain the quantile density function:

$$
q(p)=\frac{d Q(p)}{d p}, 0 \leq p \leq 1 .
$$

Order statistics play a key role in modelling using quantile functions. A more detailed explanation quantile models can be found for example in [4], [13] and [15].

\subsection{Simulation of the Extreme Values}

When simulating extreme values, it is primarily necessary to use the program for generating pseudorandom numbers. Basic pseudorandom numbers are within the interval $<0,1>$ and represent a random observation from a continuous uniform distribution on this interval. Quantile function of a uniform distribution on this interval $<0,1>$ is expressed as:

$$
S(p)=p \text { for } 0 \leq p \leq 1
$$

If using a random number generator, we can generate independent values from a uniform distribution on the interval $\langle 0,1\rangle$. In this way, the generated pseudo-random numbers and their use in the probabilistic model of any type is called simulation [7].

The basis of such simulations is Q-transformation rule. If $z=T(x)$ is a nondecreasing function of $x$ and $Q(p)$ is the quantile function, then also $T(Q(p))$ is a quantile function [7]. If is a non-decreasing function of $T(x)$ a quantile function $Q(p)$ of any distribution, the applications of $Q$-transformation rule for the case of uniform distribution quantile function $S(p)=p$ we can simulate the value of $x$ from distribution with quantile function $Q(p)$ as:

$$
x_{i}=Q\left(u_{i}\right) \quad \text { for } i=1,2, \ldots, n \text {, }
$$

where $u_{1}, u_{2}, \ldots, u_{n}$ are simulated values from a uniform probability distribution on the interval $<0,1>$. Substituting $u_{i}$ to quantile function $x_{i}=$ $Q\left(u_{i}\right)$, we obtain the arranged values $x_{(i)}$, that guarantee a non-decreasing shape of the function $Q\left(u_{i}\right)$.

The great advantage of simulation using the quantile function is that it also allows to simulate only the highest values in upper tail without necessity of simulation the central values of random variable.

We assume the right-hand tail of the probability distribution. By [7] and [13] it is possible to simulate the highest value as:

$$
x_{(n)}=Q\left(u_{(n)}\right) \text {, where } u_{(n)}=v_{n}^{\frac{1}{n}},
$$

while $v_{n}$ is a random number from the interval $<0,1>$. If ${ }^{n}$ the sequence of the transformed variables is defined in the form:

$$
\begin{aligned}
& u_{(n)}=v_{n}^{\frac{1}{n}} \\
& u_{(n-1)}=\left(v_{n-1}\right)^{\frac{l}{n-1} * u_{(n)}} \\
& u_{(n-2)}=\left(v_{n-2}\right)^{\frac{l}{n-2} * u_{(n-1)}}
\end{aligned}
$$


where $v_{i}$, for $i=n, n-1, n-2,, \ldots$, are a plurality of values generated as a random selection from a uniform distribution, then by definition values $u_{i}$, for $i=n, n-1, n-2 \ldots$, we get an increasing sequence:

$$
u_{(i-1)}<u_{i} .
$$

Values $u_{(i)}$ form an ordered sequence of values from a uniform distribution. If we get one value $u_{(n)}$, the relation for the simulation has the form:

$$
u_{(m)}=\left(v_{m}\right)^{\frac{1}{m}} * u_{(m+1)}, \text { for } m=n-1, n-2, \ldots
$$

The largest observations of variable $X$ are then simulated as:

$$
\begin{aligned}
& x_{(n)}=Q\left(u_{(n)}\right), \\
& x_{(n-1)}=Q\left(u_{(n-1)}\right), \\
& x_{(n-2)}=Q\left(u_{(n-2)}\right),
\end{aligned}
$$

\subsection{Simulation of Extreme Losses of Major Accidents}

In this part, theoretical knowledge about quantile function is applied on the data acquired from information about major accidents from the previous chapter and applied to simulate extreme losses. In total, 27 damages calculated in euros have been selected from the information systems of major accidents (EMARS, ZEMA, ARIA and PZHP). All of them took place over the years 2008-2010 and they are ordered in Table 1.

Using the statistical package STATGRAPHICS Centurion XV by the Kolmogorov-Smirnov test we have found four long tailed probability distributions well fitted to data in Table 1. Results of this test show Table 2.

According to $p$-values, the losses are best fitted by Pareto distribution model in the European form [12]:

$$
p=F(x)=1-\left(\frac{a}{x}\right)^{b}
$$

By the STATGRAPHICS Centurion output, parameters of this probability model are determined as $a=2,000,000 ; b=0.774826$. The aim is to simulate the highest five losses, considering twenty major accidents that have happened. For this, the simulation of extreme values through quantile function will be used.

Quantile function of Pareto distribution can be defined as a function inverted to the distribution function (14) in the form:

$$
x_{p}=Q(p)=\frac{a}{(1-p)^{\frac{1}{b}}}
$$

Tab. 1: Individual financial range of serious industrial accidents (in euro)

\begin{tabular}{r|r|r|r|r}
$2,000,000$ & $2,000,000$ & $2,120,000$ & $2,500,000$ & \multicolumn{1}{c}{$2,650,000$} \\
\hline $3,000,000$ & $3,000,000$ & $3,400,000$ & $3,500,000$ & $4,000,000$ \\
\hline $4,000,000$ & $4,500,000$ & $5,000,000$ & $5,100,000$ & $6,000,000$ \\
\hline $7,090,000$ & $8,400,000$ & $10,000,000$ & $12,000,000$ & $12,000,000$ \\
\hline $14,000,000$ & $14,500,000$ & $15,000,000$ & $21,050,000$ & $32,000,000$ \\
\hline $36,000,000$ & $435,000,000$ & & & \\
\hline
\end{tabular}

Tab. 2: Results of the Kolmogorov-Smirnov test

\begin{tabular}{l|c|c|c|c} 
& $\begin{array}{c}\text { Loglogistic } \\
\text { (3-Parameter) }\end{array}$ & Lognormal & $\begin{array}{c}\text { Lognormal } \\
\text { (3-Parameter) }\end{array}$ & $\begin{array}{c}\text { Pareto } \\
\text { (2-Parameter) }\end{array}$ \\
\hline DN statistics & 0.203818 & 0.137538 & 0.110012 & 0.084416 \\
\hline P-Value & 0.212352 & 0.686701 & 0.899466 & 0.990618 \\
\hline
\end{tabular}


The statistical software STATGRAPHICS Centurion randomly generated five numbers within the interval $\langle 0,1\rangle$ from an even distribution. The following calculations were done in MS Excels, using the formulae (10), (12) and (13). The result of simulation of the highest five losses out of twenty indemnities given, including the procedure, is provided in Tables 3 and 4.

Figure 2 shows the simulated damage $x=Q(u)$, further just for each order statistics $X_{(20)}, X_{(19)}, \ldots, X_{(16)}$ and also their median values $x_{0.5}$ and quantiles $x_{0.005}$ and $x_{0.995}$. In [7] and [13] is derived the calculation of the stated quantiles including beta inversion function, which is why acquired outcomes are presented only.

Table 4 makes it clear that the highest amount of claim is from the interval $<13,127,418.93 \quad € ; 88,829,890,943.26 \quad €>$ with the probability $\alpha=0.99$, while the median of the highest damage reaches the value of $156,773,540.72 €$.

These results are useful for the purposes of insurance and reinsurance.

\section{Tab. 3: Simulation of top five damages in twenty insurance indemnities}

\begin{tabular}{r|c|c|c|c|r}
$\mathbf{v}$ & $\mathbf{n}$ & $\mathbf{1 / n}$ & $\mathbf{v}^{\mathbf{1 / n}}$ & $\mathbf{u}(\mathbf{n})$ & \multicolumn{1}{c}{$\mathbf{Q}(\mathbf{u}(\mathbf{n}))$} \\
\hline 0.6489213 & 20 & 0.050000 & 0.978610 & 0.978610 & $285,810,153.50 €$ \\
\hline 0.2682335 & 19 & 0.052632 & 0.933086 & 0.913127 & $46,829,591.89 €$ \\
\hline 0.7592468 & 18 & 0.055556 & 0.984815 & 0.899261 & $38,682,768.63 €$ \\
\hline 0.3568497 & 17 & 0.058824 & 0.941186 & 0.846373 & $22,437,953.57 €$ \\
\hline 0.4219863 & 16 & 0.062500 & 0.947504 & 0.801942 & $16,165,793.88 €$ \\
\hline
\end{tabular}

Source: own calculations

\section{Tab. 4: Quantiles of ordering statistics}

\begin{tabular}{r|r|r} 
Q(BETAINV(0.5;r;n-r+1)) $\boldsymbol{x}_{\boldsymbol{0 . 5}}$ & $\mathbf{Q}\left(\right.$ BETAINV(0.005;r;n-r+1)) $=\boldsymbol{x}_{\mathbf{0 . 0 0 5}}$ & $\mathbf{Q}\left(\right.$ BETAINV(0.995;r;n-r+1)) $\boldsymbol{x}_{\mathbf{0 . 9 9 5}}$ \\
\hline $156,773,540.72 €$ & $13,127,418.93 €$ & $88,829,890,943.26 €$ \\
\hline $50,049,792.19 €$ & $8,804,780.17 €$ & $1,732,291,027.22 €$ \\
\hline $27,432,632.79 €$ & $6,806,971.44 €$ & $366,468,591.03 €$ \\
\hline $18,216,901.58 €$ & $5,613,897.44 €$ & $147,262,811.20 €$ \\
\hline $13,353,730.93 €$ & $4,810,419.62 €$ & $78,297,378.84 €$ \\
\hline
\end{tabular}

Source: own calculations

\subsection{Reinsurance of the Largest Claims}

Extreme risks, simulated in the previous chapter, need to be ensured through a combination of numerous reinsurance types. One of the most used combinations includes a reinsurance when the application of the insurance company's own retention is followed by quota reinsurance. A higher tier is ensured through non-proportional WXL/R reinsurance, and also alternative forms of reinsurance can be use.

As shows Figure 1, man-made disasters have been increasingly extensive lately. Their modelling and simulation is beneficial to riskmanagement policies of insurance companies and tackling crucial issues of their insurance and reinsurance.

Extreme-value simulation is generally used in non-proportional largest claims reinsurance $\operatorname{LCR}(p)$ or $\operatorname{ECOMOR}(p)$ reinsurance [13].

\section{Conclusion}

This article is devoted to the analysis of major industry accidents. The risks of major accidents and their consequences reach catastrophic dimensions. That is a reason to require a quality legislative modification focused on the prevention and liquidation of the consequences. The SEVESO directives No. I, II and III were sequentially released 
extent of damage

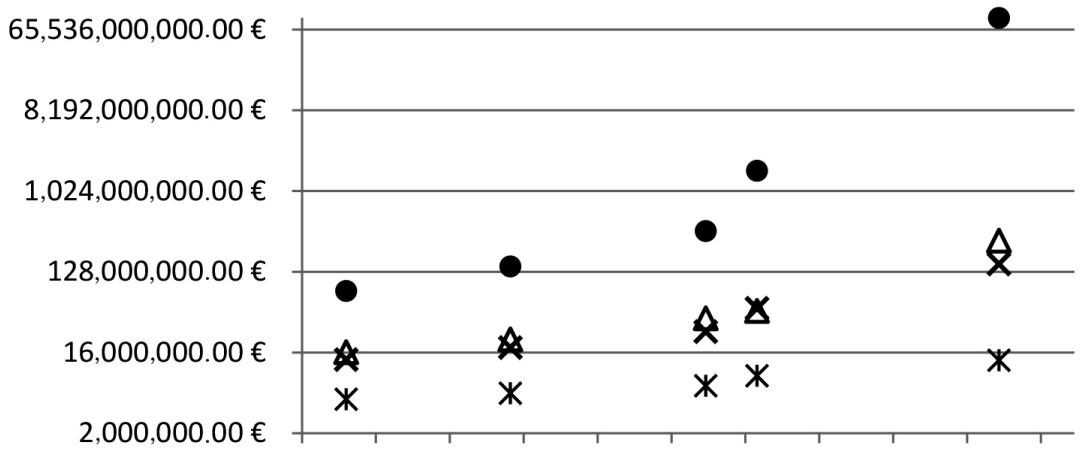

$\begin{array}{lllllllllllll}0.79 & 0.81 & 0.83 & 0.85 & 0.87 & 0.89 & 0.91 & 0.93 & 0.95 & 0.97 & 0.99 & u\end{array}$

$X Q(B E T A I N V(0.5 ; r ; n-r+1)) \bullet Q(B E T A I N V(0.995 ; r ; n-r+1)) * Q(B E T A I N V(0.005 ; r ; n-r+1)) \Delta Q(u)$

by the European Economic Community, the European Community and the European Union are implemented by individual member states into their national legislations. In the Czech Republic they are enshrined in the Act No. 59/2009 Coll. at this juncture. For the member states of the EU, OECD and UNECE there is an information system called EMARS. This system collects data about operators subject to the relevant laws and about major accidents. EMARS provides basic information about past accidents also for the general public.

For the companies in the EU area there is a legal obligation to take out liability insurance with insured sum that has to correspond to the extent of the possible damage. In the Czech Republic this obligation is established by Act No. 59/2006 Coll. It is necessary to secure every insurance contract, because the possible damage can reach catastrophic dimensions. Since there are big risks in such cases not only the classical protection but also a combination of the alternative risk transfer methods need to be used. Among the ART methods that can be used to hedge the risk of major accidents belongs the securitization of insurance risks.

In the article is used data relating to 27 major accidents for the application of the extreme damage simulation and modelling methods. With the statistic programming system STATGRAPHICS Centurion XV by using Kolmogorov-Smirnov test the Pareto distribution in European form was established as the best model of goodness of fit and also the parameter values of this distribution were estimated. Knowing the probability distribution of the amount of damages will enable the insurance company to determine the basic premium and to decide for the optimal ensuring.

Owing to catastrophic damages of major accidents, the concluding part deals with modelling and simulation of possible extreme damage. In this part was used quantile function of Pareto distribution in the European form. Simulation using quantile function enables estimation of intervals of the highest damages. This can be used in deciding about appropriate types of disproportional reinsurance and for insurance company's catastrophic risks management.

This paper was supported in terms of the project SGS FES 2014 SGSFES_2014003, entitled "Vědecko-výzkumné aktivity v Systémovém inženýrství a informatice". 


\section{References}

[1] BERNATÍK, A. Prevence závažných havárii I. 1st ed. Ostrava: Sdružení požárního a bezpečnostního inženýrství, 2006. 86 p. ISBN 80-866-3489-2.

[2] BUCHAR, V., KRAJSKÝ ÚŘAD KRÁLOVÉHRADECKÉHO KRAJE. Prevence závažných havárií podle zákona č. 59/2006 Sb., o prevenci závažných havárií: Přehled zařizení zařazených do skupin $A$ nebo $B$ [online]. Královéhradecký kraj, 2010 [cit. 2014-02-20]. Available from: http://www.kr-kralovehradecky.cz/cz/krajskyurad/ziv-prostredi-zemedelstvi/aktuality/ zavazne-havarie/prevence-zavaznychhavarii-27684/.

[3] ČESKÁ INSPEKCE ŽIVOTNÍHO PROSTŘEDÍ. Seminář $k$ 25: výročí havárie $v$ chemickém závodě Sandoz [online]. ČıžP, 2011 [cit. 2013-12-01]. Available from: http:// www.cizp.cz/3126_Seminar-k-25-vyrocihavarie-v-chemickem-zavode-Sandoz.

[4] DAVID, H.A., NAGARAJA, H.N. Order Statistics. 3rd ed. John Wiley and Sons, 2003. ISBN 0-471-38926-9.

[5] EUROPEAN COMMISSION. Chemical Accidents (Seveso I, II and III) - Prevention, Preparedness and Response [online]. Brussel: EC, 2013 [cit. 2014-02-05]. Available from: http://ec.europa.eu/environment/seveso/

[6] Europe's environment: the third assessment [online]. Copenhagen: European Environment Agency, 2003 [cit. 2014-04-21]. 343 p. Available from: http://bookshop.europa.eu/ cs/europe-s-environment-pbTH5103681/;pgid= y8dIS7GUWMdSR0EAIMEUUsWb0000cobzzj hU;sid=nEZ-q-_DwVt-u7zQmCXgDI3mm5V4e $\mathrm{OgQmpU}=$ ?CatalogCategoryID=h2YKABstrXc AAAEjXJEY4e5L. ISBN 92-916-7574-1.

[7] GILCHRIST, W.G. Statistical modelling with quantile functions. Chapman \& Hall, 2000. ISBN 1-5848-8174-7.

[8] MINISTERSTVO ŽIVOTNÍHO PROSTŘEDÍ [online]. Praha: MŽP, 2012 [cit. 2014-03-23]. Available from: http://www.mzp.cz.

[9] MINISTRY OF THE ENVIRONMENT GOVERNMENT OF JAPAN. Minamata Disease The History and Measures [online]. Tokyo: Ministry of the Environment Government of Japan [cit. 2013-12-09]. Available from: http://www.env. go.jp/en/chemi/hs/minamata2002/ch2.html.

[10] MUNGIN, L., CNN. Explosion hits fertilizer plant north of Waco, Texas [online]. CNN, c2013 [cit. 2014-03-01]. Available from: http://edition.cnn. com/2013/04/17/us/texas-explosion/index.html.

[11] Natural catastrophes and man-made disasters in 2012: A year of extreme weather events in the US [online]. Swiss Re Ltd, 2013 [cit. 2013-12-20]. Available from: http://media. swissre.com/documents/sigma2_2013_EN.pdf. [12] PACÁKOVÁ, V., GOGOLA, J. Pareto Distribution in Insurance. In: Proceedings of 9th International Scientific Conference Financial Management of Firms and Financial Institutions, 9-10 September 2013. Ostrava: VŠB - Technical University of Ostrava, 2013. pp. 648-657. ISBN 978-80-248-3172-5.

[13] PACÁKOVÁ, V., LINDA, B. Simulations of Extreme Losses in Non-Life Insurance. $E+M$ Ekonomie a Management. 2009, Vol. 12, Iss. 4, pp. 97-102. ISSN 1212-3609.

[14] PACÁKOVÁ, V., KUBEC, L. Modelování katastrofických škod. Scientific Papers of the University of Pardubice, Series D. 2012, Iss. 3, pp. 125-134. ISSN 1211-555X.

[15] SIPKOVÁ, L'., SODOMOVÁ, E. Modelovanie kvantilovými funkciami. Bratislava: EKONÓM, 2007. ISBN 978-80-225-2346-2.

[16] SKŘIVÁNKOVÁ, V., TARTAL'OVÁ, A. Catastrophic risk management in non-life insurance. $E+M$ Ekonomie a Management. 2008, Vol. 11, Iss. 2, pp. 65-72. ISSN 1212-3609. [17] Sbírka zákonů [online]. Zlín: AION CS, c2014 [cit. 2014-02-23]. Available from: http:// www.zakonyprolidi.cz/cs/sbirka.

[18] EUR-lex [online]. Úřad pro publikace Evropské unie, c2014 [cit. 2014-05-21]. Legal information system. Available from: http://eurlex.europa.eu/homepage.html?locale=cs.

Mgr. Pavla Jindrová, Ph.D. University of Pardubice Faculty of Economics and Administration Institute of Mathematics and Quantitative Methods Pavla.Jindrova@upce.cz

Bc. Radim Jakubínský University of Pardubice Faculty of Economics and Administration Institute of Mathematics and Quantitative Methods Jakubinsky.Radim@gmail.com 


\section{Abstract}

\section{SIGNIFICANCE AND POSSIBILITIES OF MAJOR ACCIDENT INSURANCE}

\section{Pavla Jindrová, Radim Jakubínský}

The development of human society is placing ever increasing demands on their production. This action brings the company not only positive but also negative impacts. Along with the development of industrial production, people have to face the risks posed their activity brings. The accidents, which occurred in the recent past, they still have a negative impact not only on humans but also on the environment and the economy. In this paper, we address the issue of major accidents. Major accidents are meant only accidents caused induced by human activities. The paper presents the best known major accidents since the beginning of the 20th century. They have come in the European Union to modify the legislation that is valid for the all EU Member States. In the Czech Republic, these rules are enshrined in Act No. 59/2009 Coll., on the prevention of major accidents. For human society is a necessary protection against the effects arising from major accidents. One of the possibilities is the insurance of major accidents. Since in major accidents frequently occurs very high damage is therefore utilized modelling and simulation of extreme values. One of the options that can be used is modelling using the quantile function. The paper recalled model and process simulation of extreme values. It is possible to estimate the values of the damage amounts thanks to the help of the simulation of the quantile function, and it is also possible to estimate the maximum limit of the interval of damage. This knowledge can be used in deciding on the appropriate type of non-proportional reinsurance and also for the management of catastrophic risk insurance.

Key Words: Major accident, probability models, quantile function, extreme values, simulation, insurance.

JEL Classification: C13, C15, C16, G22.

DOI: 10.15240/tul/001/2015-4-009 